\title{
FRANZ JOSEF AND OTHER GLACIERS OF THE SOUTHERN ALPS, NEW ZEALAND
}

\author{
By R. P. Suggate \\ (New Zealand Geological Survey, Greymouth)
}

\begin{abstract}
Published literature on the glaciers of the Southern Alps, New Zealand, and the Franz Josef Glacier ABSTRACT. Published under the headings of (I) rates of movement, and (2) evidences of advance and retreat. in particular, is reviewed under the headings of (I) rates of movement, and Comparison of available rainfall statistics with the dates of advance and retreat of this glacier suggests the peen at the terminal face about five years after such periods began.

Zusammenfassung. Die über die Gletscher der Southern Alps, Neuseeland, und insbesondere über den Franz Jen Josef Glacier veröfentlichte Lifür Vorstoss und Rückzug. Wenn man vorhandene Statistiken über Regenfälle mit schwindigkeit, und 2) Beweise für Vorstoss und Retschers vergleicht, so lässt sich vermuten, dass Vorstösse auf den Daten des Vorstosses und Rückzugs dieses Gletschers vergleicht, so lässt sich vermuten, Niederschlags. Die Folgen sind etwa 5 Jahre nach Beginn solcher Perioden am Gletscherende zu sehen.
\end{abstract}

\section{INTRODUCTION}

When the more remote areas of New Zealand were first being explored and surveyed much interest was displayed in the glaciers of the Southern Alps. On both sides of the range surveys of the glaciers were made, notably by Brodrick ${ }^{3,4}$ on the east side and Harper ${ }^{10,11}$ on the west side, and these early reports are unlikely to be bettered for general descriptions of the glaciers. Apart from the important papers of Speight, ${ }^{16,17,18,19}$ which record the history of the Franz Josef Glacier up to 1940 , few subsequent observations were made, although Brodrick's records of movements of marked stones on the Mueller Glacier, ${ }^{5}$ and the report of the Geological Survey by Bell ${ }^{2}$ on the Franz Josef Glacier are exceptions.

The glaciers of the Southern Alps are best developed in the highest part of the range - the Mt. Cook (12,349 ft. ; 3813 m.) district. Numerous small glaciers are situated close to the main divide for a distance of 80 miles ( $128 \mathrm{~km}$.) north-east from Mt. Cook. Ninety miles ( $145 \mathrm{~km}$.) south-west of this mountain other small glaciers are found in the region of Mt. Aspiring ( $9975 \mathrm{ft}$. ; $3040 \mathrm{~m}$.). Fig. I (p. 423) shows the distribution of the glaciers in the Southern Alps. The slope from the crest of the range is steep to the west and relatively gentle to the east, in which direction most of the larger glaciers flow. The most important glaciers flowing westwards towards the Tasman Sea are the Franz Josef and the Fox, which terminate below rooo ft. $(305 \mathrm{~m}$.) in densely forested areas. To the east the main glaciers are those which flow to the Hooker River near the Hermitage, the Mueller Glacier from the south-wext, the Tasman and Hooker Glaciers from the north and the Murchison Glacier from the north-north-east.

Snow is brought by the prevailing winds from the west, and although there are no figures available for the precipitation on the snowfields, this is probably over $200 \mathrm{in}$. $(508 \mathrm{~cm}$.) well distributed throughout the year.

\section{Rates of Movement}

Observations towards the end of the last century provide most of the information available on the rates of movement of the glaciers. The table on page 424 summarizes the available records.

In general, as is to be expected, the higher rates of movement are recorded for stations in the centre of the glacier.

Rose ${ }^{14}$ discusses the rate of movement of the Murchison Glacier as obtained from the positions of the end of a prominent area of surface moraine recorded in photographs taken in I9I4 and I935. He states that the "rate of movement is 10.3 in. $(28 \cdot 2 \mathrm{~cm}$.) a day, a figure which agrees reasonably well with Brodrick's results for the median portion of the glacier." (See Table.) 


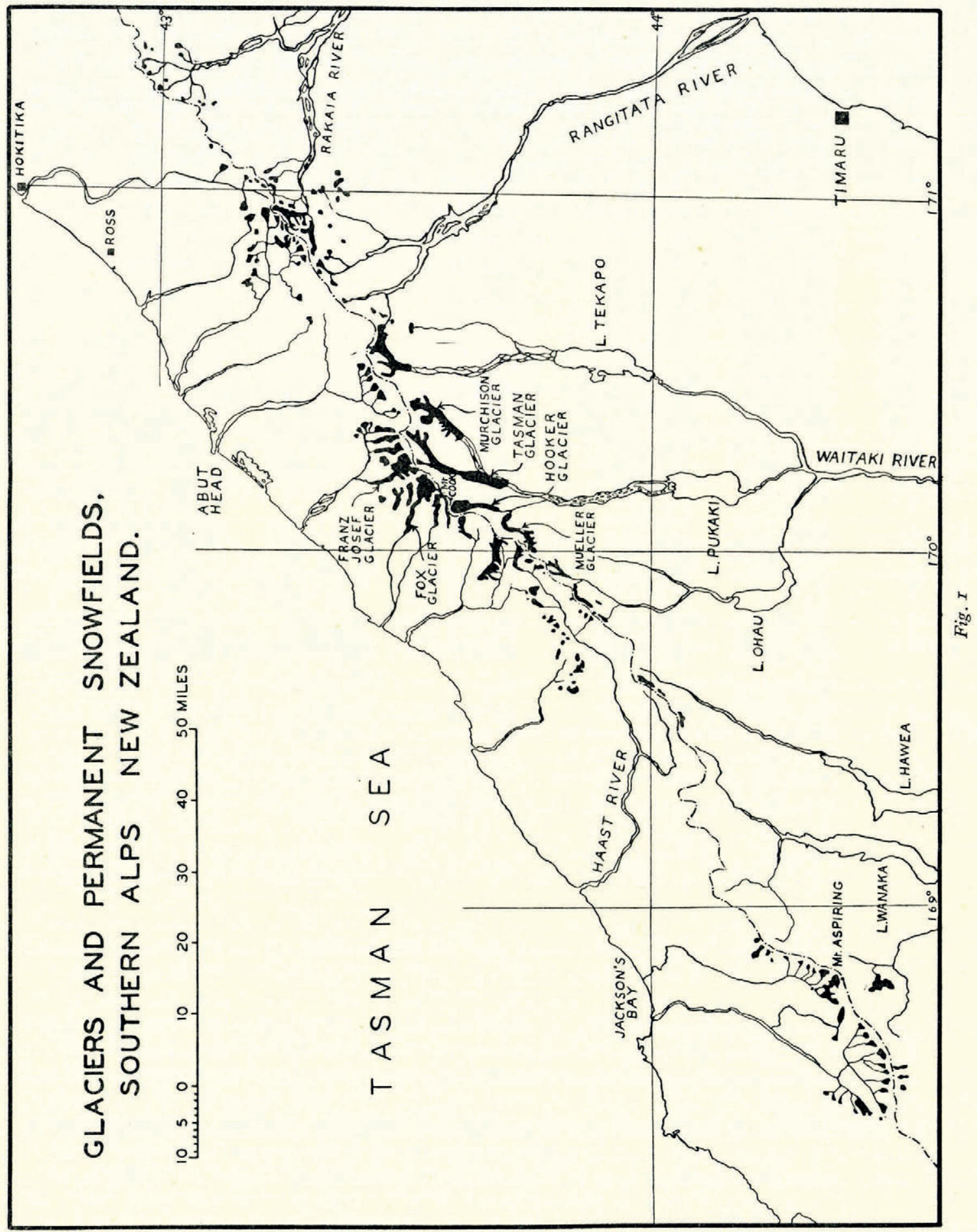


The evidence from the Tasman and Mueller Glaciers shows that the rate of movement decreases towards the terminal face. Thus the centre of the Tasman Glacier moves at about 26 in. $(66 \cdot 0 \mathrm{~cm}$.) a day at 12 miles $(19.3 \mathrm{~km}$.) from the terminal face (Cotton 7, p. 277$), \mathrm{r} 8 \mathrm{in} .\left(45^{\circ} 7 \mathrm{~cm}\right.$.) a day at 7 miles $\left(\mathrm{Ir} \cdot 3 \mathrm{~km}\right.$.), and $\mathrm{r}_{3}$ in. $\left(33^{\circ} \circ \mathrm{cm}\right.$.) a day at 6 miles $\left(9 \cdot 7 \mathrm{~km}\right.$.) (Brodrick $\left.{ }^{4}\right)$. Speight ${ }^{20}\left(\mathrm{p} . \mathrm{I}_{34}\right)$ gives reasons for suggesting that it is only 4 or $5 \mathrm{in}$. (I0.1 cm. or $12.7 \mathrm{~cm}$.) a day near the terminal face. As a result of the decrease in the rate of movement towards the terminal face and the scattered locations of observations on the different glaciers, comparison of speeds is difficult. It is generally thought that those on the western side of the Southern Alps are faster than those on the eastern side; Speight ${ }^{19}$ (p. I43) contrasts the Tasman Glacier "with low speed and on a low gradient" with the Franz Josef Glacier "on a steep gradient and with rapid flow."

\begin{tabular}{|c|c|c|c|c|c|c|c|c|c|c|c|}
\hline \multirow{3}{*}{\multicolumn{2}{|c|}{ Glacier }} & & & \multirow{3}{*}{ Date } & \multicolumn{4}{|c|}{ Average rates } & \multicolumn{2}{|c|}{$\begin{array}{c}\text { Distance from terminal } \\
\text { face }\end{array}$} & \multirow{3}{*}{ Reference } \\
\hline & & & & & \multicolumn{2}{|c|}{ (in. per day) } & \multicolumn{2}{|c|}{ (cm. per day) } & \multirow{2}{*}{ (Miles) } & \multirow{2}{*}{$(K m)}$. & \\
\hline & & & & & Max. & Min. & Max. & Min. & & & \\
\hline $\begin{array}{l}\text { Franz Josef } \\
\text { Franz Josef } \\
\text { Franz Josef } \\
\text { Fox } \\
\text { Fox } \\
\text { Tasman. } \\
\text { Tasman. } \\
\text { Murchison } \\
\text { Hooker. } \\
\text { Mueller. }\end{array}$ & $\begin{array}{l}\dot{.} \\
\dot{.} \\
\dot{.} \\
\dot{.} \\
\dot{.}\end{array}$ & . & $\begin{array}{l}\dot{.} \\
\dot{.} \\
\dot{.} \\
\dot{.} \\
\dot{.} \\
\dot{.}\end{array}$ & $\begin{array}{c}\text { I } 894 \\
1894 \\
1908 \\
1894 \\
1932 \\
1890-91 \\
1890-91 \\
1890 \\
1889 \\
1889-98\end{array}$ & $\begin{array}{r}207 \cdot 0 \\
132.8 \\
24.0 \\
13.4 \\
21 \cdot 2 \\
18.0 \\
13.3 \\
8.7 \\
5.4 \\
12.3\end{array}$ & $\begin{array}{r}23 \cdot 6 \\
5 \cdot 0 \\
9 \cdot 5 \\
3 \cdot 0 \\
7 \cdot 5 \\
9 \cdot 9 \\
2 \cdot 4 \\
0 \cdot 5 \\
1 \cdot 1 \\
2 \cdot 2\end{array}$ & $\begin{array}{r}525 \cdot 8 \\
337 \cdot 3 \\
61 \cdot 0 \\
34 \cdot 0 \\
53 \cdot 9 \\
45 \cdot 7 \\
33 \cdot 8 \\
22 \cdot 1 \\
13 \cdot 7 \\
31 \cdot 3\end{array}$ & $\begin{array}{r}59 \cdot 9 \\
12 \cdot 7 \\
24 \cdot 1 \\
7 \cdot 6 \\
19 \cdot 1 \\
25 \cdot 2 \\
6 \cdot 1 \\
1 \cdot 3 \\
2 \cdot 8 \\
5 \cdot 6\end{array}$ & \begin{tabular}{|c|}
2 \\
1 \\
$\frac{1}{3}$ \\
About $I \frac{1}{2}$ \\
$\frac{3}{4}$ \\
7 \\
6 \\
Various $\frac{1}{2}-2$
\end{tabular} & $\begin{array}{c}3 \cdot 2 \\
\mathrm{I} \cdot 6 \\
0 \cdot 53 \\
\text { About } 2 \cdot 4 \\
\mathrm{I} \cdot 2 \\
\mathrm{II} \cdot 3 \\
9 \cdot 7 \\
\mathrm{I} \cdot 2 \\
0.8-3 \cdot 2\end{array}$ & $\begin{array}{c}\text { Harper }{ }^{11} \\
\text { Bell'"2 } \\
\text { Wilson }^{21} \\
\text { Speight }^{18} \\
\text { Brodrick }^{4} \\
\quad, " \\
\quad " \\
\text { Brodrick }\end{array}$ \\
\hline
\end{tabular}

The recorded observations for the Franz Josef Glacier must be considered in this light. The extraordinarily rapid rates of movement observed by Harper ${ }^{11}$ in 1894 seem out of all proportion to the other recorded rates. Harper's comments are, however, worth recording. He states (p. 77) that " $\ldots$ at the best only rough and approximate figures can be obtained with a compass ;.. The results of our observations are astonishing ... but, when it is possible with the naked eye to see a difference in the position of a mark after 24 hours, there is little doubt that the figures are not far out." Taken together with Greville's measurements in 1908 recorded by Bell ${ }^{2}$ (p. 7) these give a decrease in speed at the centre of the glacier from 207 in. $(526 \mathrm{~cm}$.) a day 2 miles $(3.2 \mathrm{~km}$.) from the terminal face to $\mathrm{r} 32 \cdot 8 \mathrm{in}$. $(337 \mathrm{~cm}$.) a day at $\mathrm{I}$ mile $(\mathrm{r} \cdot 6 \mathrm{~km}$.$) , and 24 \mathrm{in}$. $(6 \mathrm{r} \cdot 0 \mathrm{~cm}$.$) a day at$ $\frac{1}{3}$ mile $(0.53 \mathrm{~km}$.). When compared with the figures for the Tasman Glacier the far greater speed near the terminal face ( 24 as against 4 or 5 in.) makes it probable that far greater speeds are also to be expected higher up the glacier. The exceptionally high rates of movement may in fact be reasonably accurate, but comparison with the Fox Glacier, where conditions might be expected to be very similar, does not support this. The observations by Hume in 1932 recorded by Speight 18 (p. 32I) $\frac{3}{4}$ mile $(\mathrm{r} \cdot 2 \mathrm{~km}$.) from the terminal face show a greater speed than was recorded by Wilson ${ }^{21}$ (p. I09) at $\mathrm{I}_{2}^{\frac{1}{2}}$ miles $(2 \cdot 4 \mathrm{~km}$.) from the terminal face. Both these sets of observations give speeds of the same order as those measured by Greville for the Franz Josef Glacier in I908. It is clear that accurate measurements of rates of movement in different parts of that glacier would be of great value.

The difference in rates of movement from one period of time to another are difficult to assess, but some information is given by Brodrick's measurements of the movement of marked stones at distances from about $\frac{1}{2}$ mile to 2 miles $(0 \cdot 8-3 \cdot 2 \mathrm{~km}$.) from the terminal face of the Mueller Glacier. Some of the stones further up the glacier passed over similar courses to those traversed some years 


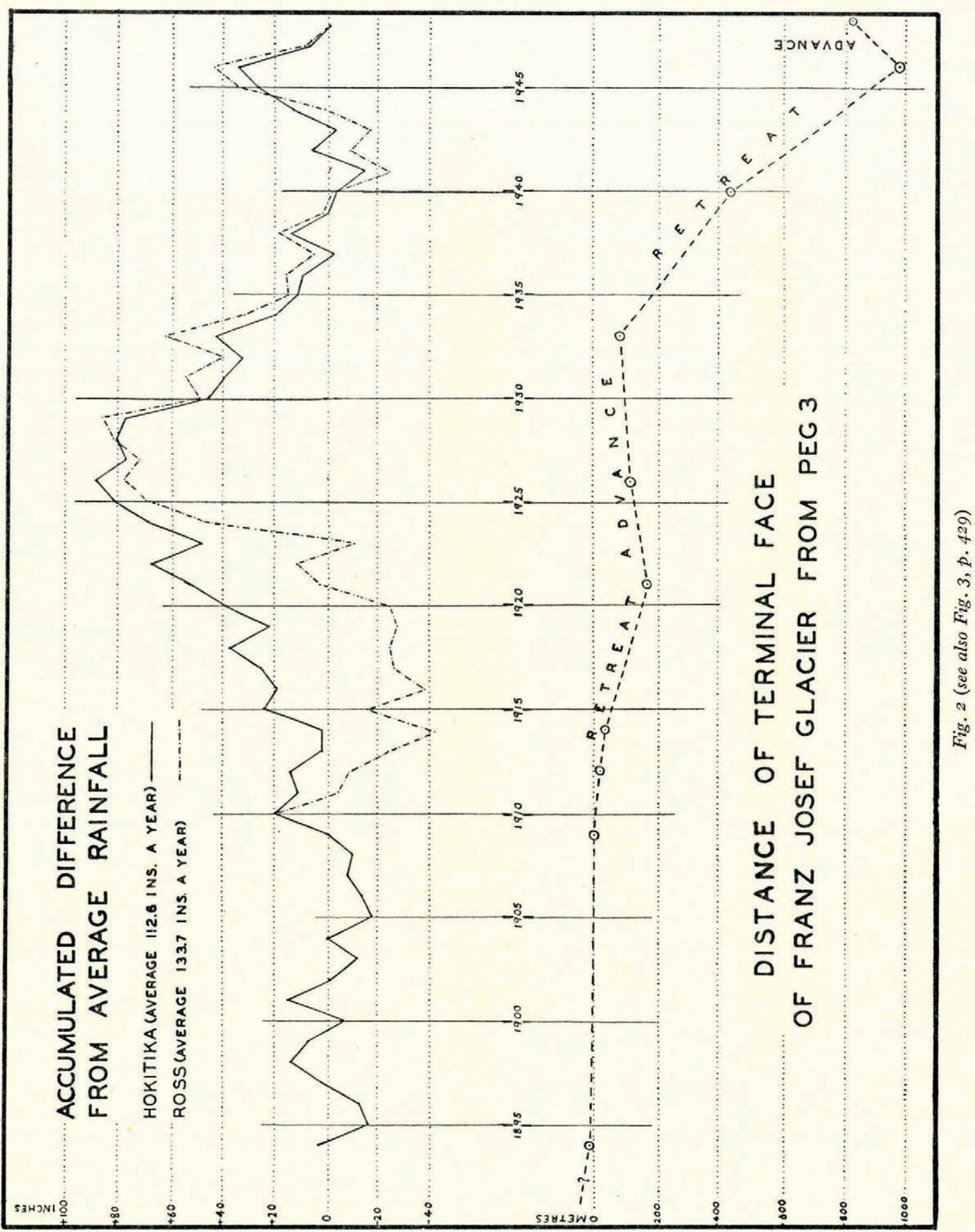


before by those lower down. The best comparisons available from his observations ${ }^{6}$ give differences of between I and 2 in. $(2 \cdot 5-5 \cdot 0 \mathrm{~cm}$.) a day between earlier and later passages over similar courses. Seasonal variation is likewise not reliably indicated from available information. Brodrick 6 notes that summer rates of the Mueller Glacier in 1898 were distinctly higher than the average rate over a number of years. Perhaps also the greater speed of the Fox Glacier at $\frac{3}{4}$ mile $(\mathrm{r} \cdot 2 \mathrm{~km}$.) from the terminal face than at $I_{2} \frac{1}{2}$ miles (the opposite might be expected) is due to the former observations having been taken in summer and the latter in winter.

\section{Evidences of Advance and Retreat}

Only scattered observations have been published on glaciers other than the Franz Josef. Harper 10 writing in 1893 observed that on the whole the glaciers were then retreating, in some cases, such as the various small glaciers at the head of the Rangitata River, very rapidly; in others, such as the larger glaciers, more slowly. Harper's paper, and one by Baker ${ }^{1}$ are based largely on reports by Brodrick ${ }^{3,4}$ who also noted that some tributary glaciers to Murchison Glacier showed signs of advance, others appeared to be stationary while many gave definite evidence of retreat. Hutton ${ }^{12}$ (p. 438), in a description of the Mueller Glacier, considered that in the previous eleven years the terminal face had retreated from 250 to $300 \mathrm{yd}$. $\left(230-275 \mathrm{~m}\right.$.). In 1906 Brodrick ${ }^{6}$ records that between $\mathrm{I} 889$ and that year the Mueller and Tasman Glaciers had advanced slightly, and notes that the advance of the Mueller Glacier took place despite a decrease in the rate of movement of about $I$ in. $(2 \cdot 5 \mathrm{~cm}$.) a day from the period $1889-1895$ to the period $1895-1906$. Speight 15 notes that the Cameron Glacier south-east of Mt. Arrowsmith and the Ramsay and Lyell Glaciers at the head of the Rakaia River all showed signs of retreat.

More details are known of the advances and retreats of the Franz Josef Glacier. The first survey showing the position of the terminal face was made by Harper, ${ }^{11}$ and in his description he notes that 'from sketches taken from 'the flats,' about 20 years ago, at the terminal face it would seem that there has been a slight but steady annual retreat." Bell ${ }^{2}$ records the position of the terminal face in 1909 as further back than it was in 1894 , but states that some advance in the previous few years was noticeable. Speight ${ }^{16}$ notes that "the glacier had retreated since I909 an average of about $\mathrm{I} 70 \mathrm{ft}$. $(52 \mathrm{~m}$.) across the face," and further observations of the terminal face by the same author ${ }^{17,18,19}$ are summarized in a map in his $194 \mathrm{I}$ paper. ${ }^{19}$ Until 1920 the glacier continued to retreat, but advance then took place until 1934 or 1935 . From then until late 1946 the terminal face retreated since when an advance has taken place and is now (October 1949) continuing at an average rate of $\mathrm{I} \mathrm{ft} .(30.5 \mathrm{~cm}$.) a day.* Speight 19 discusses the possible causes of the retreat then taking place, but concludes (p. I33) that "the real cause for the abnormal retreat of the glaciers within the last few years cannot be definitely assigned."

Fig. 2 (p. 425) shows the movement of the terminal face of the Franz Josef Glacier from I894 until i 948 , and also the accumulated difference from normal of rainfall as recorded at Ross and Hokitika, the two nearest meteorological stations for which reliable statistics are available. I am indebted to Dr. Barnett, Director of Meteorological Services, Wellington, for the rainfall information. Ross is 50 miles $\left(80 \mathrm{~km}\right.$.) and Hokitika 65 miles ( $\mathrm{r}_{5} \mathrm{~km}$.) north-east of the Franz Josef Glacier, the figures for Hokitika being used only because none are available for Ross prior to I9ro. The same general trends are shown by the records of both Hokitika and Ross, but the differences between 1910 and 1920 are noticeable. A graph giving accumulated differences from average shows most clearly the effects of low or high precipitation over a number of years in succession.

\footnotetext{
* When its retreat was at a maximum in 1946 the terminal face was relatively straight, extending westwards across the valley from near the mouth of Arch Creek, and the river flowed from a point near the eastern side of the glacier. In front the eastern part of the area between the glacier and Park Rock was occupied by river gravel and silt, the eastern part being a lake. During the recent advance the glacier has pushed forward right across its front, and changes in the river have caused the draining of the lake.

A recent photograph of the snout is reproduced on page 438 .
} 
The position of the terminal face is plotted as distances in metres from Peg 3 (one of the pegs placed on rocks in front of the terminal face by Bell in 1909). The figures up to I 934 are taken from Speight ${ }^{18}$ (p. $3^{16}$ ), the position in 1940 from the same author's later paper ${ }^{19}$ (p. 130). The 1946 position was only roughly located from photographs and as a result the extent of the present advance is not accurately known. Peg 3 has been chosen as the distances from this peg are the most representative of the general movement of the glacier as shown by Speight's map. ${ }^{19}$ Large roches moutonnées in front of the glacier interfered with the direct advance and retreat of the terminal face towards the close of last, and the beginning of this, century.

Comparison of the periods of advance and retreat of the glacier with the periods when the accumulated difference from normal of rainfall was increasing or decreasing suggests that the amount of precipitation brought by the prevailing westerly winds may, at least in part, account for the glacier fluctuations. Thus during the period I894-1909 the rainfall at Hokitika showed no persistent departure from normal, and until about 1914 no large movements of the glacier's terminal face were recorded. From I910 to I9I4 an accumulated deficit of rainfall was recorded at Ross, and heavy rainfall in 1918 was countered by light rainfall in 1916 . A significant, though not large, retreat of the glacier took place up to 1920 . From 1917 to 1929 there was an almost unbroken upward trend in the accumulated excess of rainfall at Ross, and advance of the glacier is recorded until I934 or perhaps I935, although this did not take the glacier as far forward as it had been 25 years before. An increasing deficit in rainfall from 1929 to $194 \mathrm{I}$ was followed by a large retreat in the glacier's terminal face from 1934 to 1946 . An excess of rainfall is recorded from 1942 to 1946 and the glacier advance began in late 1946 or early 1947 .

The above comparisons suggest a lag of about 5 years between the periods of high or low precipitation and a corresponding advance or retreat of the glacier. For the first of the accumulated snow to take 5 years to reach the terminal face requires an average speed of about $200 \mathrm{in} .(508 \mathrm{~cm}$.) a day over the whole length of the glacier, this figure suggesting that the high rates of movement recorded by Harper are probably correct. That the effect of precipitation is not the whole of the story is suggested by the differences in magnitude between the major advance and the major retreat recorded, the extent of retreat being about nine times the extent of advance for a very similar amount of accumulated excess or deficit of rainfall. It may be that the major fluctuations seen at the terminal face are the effects of advance or retreat due to precipitation variation being superimposed on a slight general retreat; it has been noted that there was a small retreat from I 894 to I9IO, when there was no major fluctuation from normal in rainfall as recorded at Hokitika. Other factors, such as the temperature conditions, the proportion of precipitation actually falling as snow, and the amount of sunshine must all play their parts. (See note on page 428 .)

The periods of advance and retreat for the Fox Glacier have been to a large extent similar to those for the Franz Josef, as is only to be expected in view of the similarity of their locations and courses although no large recent advance has taken place. But the major glaciers on the eastern side of the Southern Alps do not show comparable records. In general their terminal faces have not changed greatly in position since they were first surveyed towards the end of last century. Speight, ${ }^{20}$ however, has pointed out that, in contrast to the west coast glaciers, the Tasman and others on the east side of the main range show signs of ice-wasting over a considerable length of their course. The Tasman Glacier even showed signs of advance at the terminal face, while the effects of wasting were at the same time remarkably evident. The conditions on the snowfields at the heads of all the glaciers, flowing both to the west and the east of the divide, must be more or less similar, but in other respects conditions are very different. On the east side the precipitation is less, and the temperature conditions, especially on the lower parts of the glaciers, are less equable. A further important difference is that for several miles above the terminal face of the major glaciers on the eastern side of the main range (Tasman, Murchison, Mueller and Hooker Glaciers) the surface of the ice is covered by moraine, whereas the Franz Josef and Fox Glaciers on the 
western side are almost clear of moraine. Some differences between the behaviour of the glaciers on different sides of the Southern Alps are thus to be expected, but there is at present insufficient information to make accurate comparisons.

The New Zealand glaciers are easily accessible. It should, therefore, not be difficult to carry out regular observations of the rates of movement and of the advance and retreat of the glaciers on both sides of the Southern Alps. Many of these observations could conveniently be made by frequent photographs from fixed points, especially in view of the great difference in gradient, speeds and the phenomena of advance and retreat. Such observations would be of much value.

$M S$. received 8 November 1949 .

\section{R E F E R E N C E S}

I. Baker, J. H. On Mount Cook Glacier motion. Report Australasian Association for the Advancement of Science, Vol. 3 , I 891 , p. 1 $53-61$.

2. Bell, J. M. A geographical report on the Franz Josef Glacier. New Zealand Geological Survey, r9ro, 14 p.

3. Brodrick, T. N. Report on the glaciers of Mount Cook. Appendix to the fournal of the House of Representatives of New Zealand, r 889 , Vol. r, C-1A, appendix No. 4, p. 32-33.

4. Report on the Tasman Glacier. Appendix to the Fournal of Representatives of New Zealand, $189 \mathrm{I}$, Session II, Vol. r, C-rA, appendix No. 4, p. 39-43.

5 ' Mueller Glacier. Appendix to the fournal of the House of Representatives of New Zealand, I905, Vol. I, C-I, appendix No. 9, p. II 2 . 6. Glacier movements. Appendix to the Fournal of the House of Representatives of New Zealand, r9o6, Sesion II,

7. Cotton, C. A. Geomorphology of Nerv Zealand. Wellington, Dominion Museum, 1922.

8. Douglas, C. E. and Harper, A. P. The Westland Alps, New Zealand. Geographical fournal, Vol. 5, No. 1, 1895, p. $6 \mathrm{r}-68$.

9. Hardcastle, J. On the Timaru Loess as a climatic register. Transactions of the New Zealand Institute, Vol. 23, I890, p. 324-32.

ro. Harper, A. P. Exploration and character of the principal New Zealand glaciers. Geographical fournal, Vol. r, No. r, I893, p. 32-42.

Ir. The Franz Josef Glacier. Appendix to the fournal of the House of Representatives of Nerw Zealand I894, Vol. r, C-1, appendix No. 6, p. $75-79$.

12. Hutton, F. W. Notes on the Mueller Glacier, New Zealand. Proceedings Linnean Society New South Wales (Second Series), Vol. 3, Part 2, r 888 , p. 429-42.

13. On the veined structure of the Mueller Glacier. Nature, Vol. 38, No. 969, 1888, p. $77-78$.

14. Rose, J. H. Recent retreat of Murchison Glacier. New Zealand Fournal of Science and Technology, Vol. 19, 1938, p. 453-57.

15. Speight, R. The Mount Arrowsmith district: a study in physiography and plant ecology. Part I, physiography. Transaction New Zealand Institute, Vol. 43, 1910, p. 317-42.

16. - Recent changes in the position of the terminal face of the Franz Josef Glacier. Transactions New Zealand Institute, Vol. 47 , 1914, p. $353-54$.

17. - Recent changes in the terminal face of the Franz Josef Glacier. Transactions New Zealand Institute, Vol. 53,

18. I92 I, P. 53-57. p. $315-22$.

19. - Note on the Franz Josef Glacier, December 1940. Transactions Royal Society of New Zealand, Vol. 7r, Pt. 2, 20. I94I, p. 128-33.

20. Ice wasting and glacier retreat in New Zealand. Fournal of Geomorphology, Vol. 3, Pt. 2, I940, p. $13 \mathrm{I}-43$.

21. Wilson, W. The Fox Glacier. Appendix to the Fournal of the House of Representatives of New Zealand, I896, Vol. 1, C-r, appendix No. 8, p. 108-9.

A subsequent communication dated II May 1950 has been received from $\mathrm{Mr}$. Suggate in which he writes:

"Since I tried to relate the movements of the Franz Josef Glacier to the rainfall, I have obtained temperature and sunshine figures for Hokitika. These are shown in the accompanying graphs (Fig. 3, p. 429). It is perhaps significant that the advance of the Franz Josef Glacier follows a period from 194I to 1946 when not only was the rainfall above average but the temperature and sunshine figures were below average." 


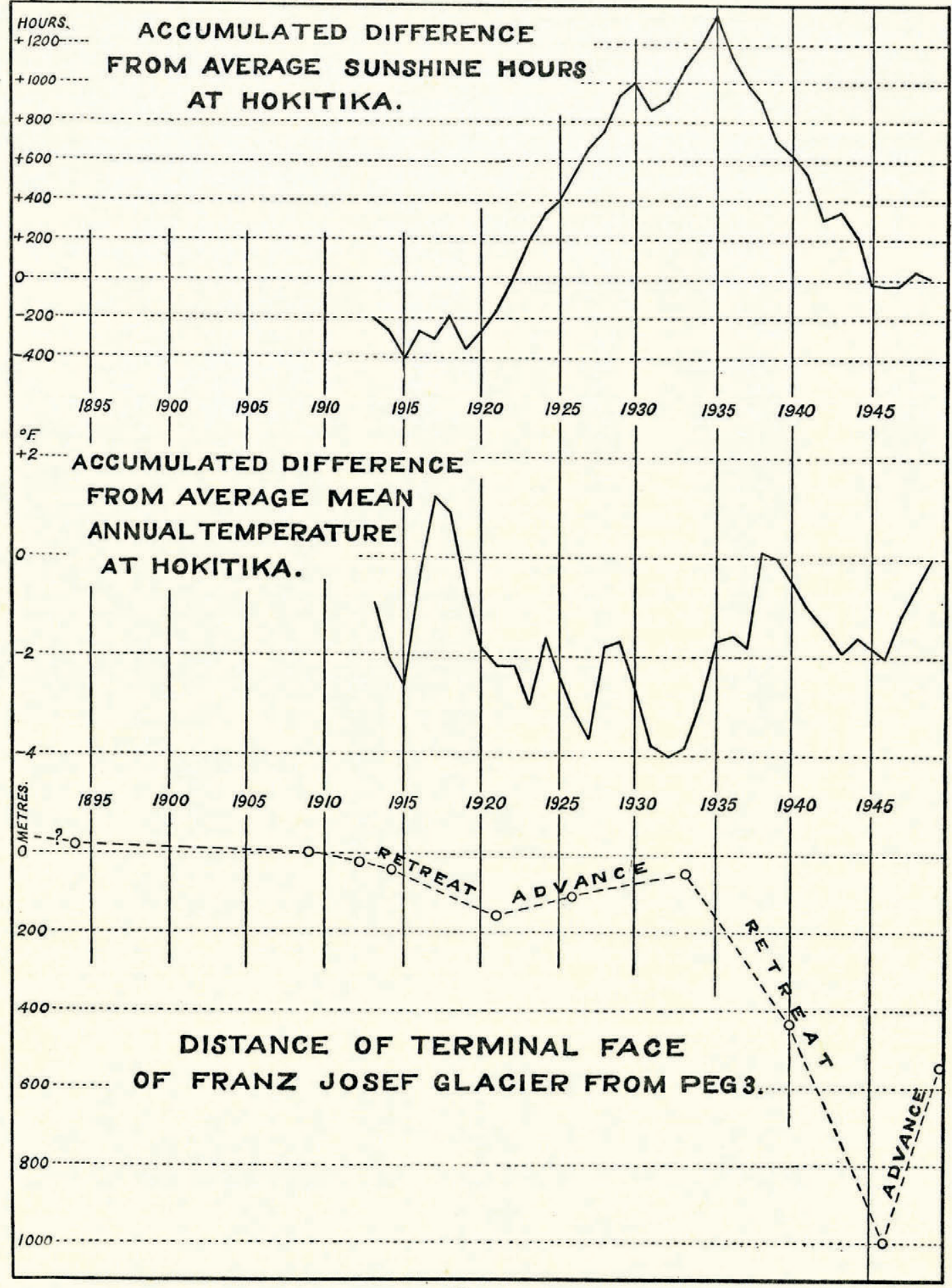

Fig. 3 